\begin{tabular}{ccc}
\hline Mournals & MARKETING AND BRANDING & INDUSTRIAL \\
RESEARCH & MANAGEMENT \\
& wWw.AIMIJOURNAL.COM & INSTITUTE \\
\hline
\end{tabular}

\title{
Business ethics from the perspective of Islamic economics
}

Keywords: Ethics, Production, Trade, Islamic Economics

Correspondence: davood_tab@yahoo.com

\author{
Aziz Javanpour, Davood Norouzi*
}

Department of Management, Tabriz Branch, Tabriz, Iran

Young Researchers and Elite Club, Tabriz Branch, Islamic Azad University, Tabriz, Iran

\begin{tabular}{ll}
\hline & ABSTRACT \\
\cline { 2 - 2 } $\begin{array}{l}\text { Keywords: } \\
\text { Ethics, Production, Trade, }\end{array}$ & $\begin{array}{l}\text { The present study aims to contribute to the existing research in the field of business and shed } \\
\text { more light on the business ethics from the perspective of Islamic economics. Assessing the } \\
\text { Islamic Economics }\end{array}$ \\
$\begin{array}{l}\text { compatibility and incompatibility of economic development indicators with Islamic doctrines } \\
\text { is main focus and central topic of this study. Nowadays, most Islamic countries are } \\
\text { observed to be among underdeveloped or developing countries. Therefore, it is necessary to }\end{array}$ \\
$\begin{array}{l}\text { Correspondence: } \\
\text { davood_tab@yahoo.com a study in order to know whether Islamic teachings are barrier for accelerating the } \\
\text { commercial business from the perspective of Islamic economics are discussed. }\end{array}$
\end{tabular}

(C)AIMI Journals

\section{Introduction}

Islam is a complete way of life and it is not merely a religion. Its teaching expands into all areas of life. It has provided comprehensive principles to conduct and guide the various economic aspects in the society. Muslims are to recognize that wealth, earnings and material goods are the property of God and humans are merely His trustees. It is argued that in the climate of Islamic philosophy, it is ethics that influence economics and not vice versa (Naqvi, 1981) and Islamic economics is characterized as being ethical.

Islam does not support the greed for property, wealth, attainment of high power and glory. It encourages man to attain material prosperity within proper limits, because without material 
prosperity the ideal of welfare does not remain complete. It is proposed that an ethical environment pave the way and provide the ground to improved performance. Also, it provides crucial support for maximizing continuing owner value (Sternberg, 2000).

The Islamic work ethics tend to be notably informative for studying. On the one hand, the significance of work is high in modernizing economics and among countries Islam is of importance. On the other hand, Islam is well-known across the world in regions with a divers degree of prosperity. For many years, economists have been attempted to understand why Islamic countries have not quickly modernized in the last fifty years, considering that the Islamic doctrines as such is not opposed to economic progress (Wang \& Young, 2011).

In order to function more effectively, both businesses and individuals should consider ethics. The lack of an ethical structure ruling actions leads to the absence of behavior standards that is necessary for a civil society and would result in chaos and disorder (Stewart, 1996). Ethics has always been a part of economics and many have discussed ethics for centuries. Ethics are the principles of human conduct concerning either an individuals or a group (Shaw, 1999), and business ethics refer to what is right and wrong, or what is good or bad in business transactions (Weiss, 1994). Thus, specific ethical knowledge and skill are what people need in dealing ethically in different situations.

There is no single definition related to business ethics. Great distraction exists when business ethics is noticed in any discourse (Jones, Parker, \& Ten Bos, 2005). Apparently, business ethics is concerned with moral codes and rules of conduct in the field of business (Chryssides \& Kaler, 1993). Schwartz and Weber (2006) explained business ethics as being any formal activity taking place between individuals, organizations, or other institutions functioning within or related to a business context that requires the explicit interaction and/or implementation of ethical standards.

It has been stated by Quddus, Bailey, and White (2009) that the moral standards and ethical perceptions of people originate from the concept of their religion's background and values. Therefore, what people comprehend from the term "ethics" and how they apply it in their routine and business life represents their religious thoughts, morals and beliefs. Recently, some organizational scholars have been greatly critical of mainstream business ethics and have suggested alternative ethical approaches (Jones, 2003). Nowadays, it seems that in international competitive environment eyes are on business schools to expand our emphasis on ethics instruction (Baker \& Comer, 2012). 
Ethics often depend upon behavior that requires higher standards, and it is defined as set of standards for estimating whether a person's relationship with others is appropriate or wrong on the basis of honesty and truth (Mosley, Pietri, \& Megginson, 1996). So, this study is an attempt to bridge the perceived gap in this field of study. The following section of the article reviews the business ethics from the perspective of Islamic economics.

\section{Religious Identity}

Since the beginning of religious history, religion always had positive and effective role in defining civil and social identity of humankind. If the remarkable effect of religions in creating an entire civilization is acceptable, then it could be argued that religion plays a determinant role among the elements of human culture. In other words, religious culture can be life-saving. Also, it can lead to entrepreneurial development and can bring civilization. Religious identity can be studied at two levels, namely the individual level, synonymous with personal piety, and the collective level, equivalent to a religious community or nation (Moeedfar, 1999). Religious identity is complex concept and includes several aspects such as faith issues, rites and rituals, and historical, social, and cultural issues. Religious beliefs and behavior are strongly linked to people's lives and have profound reflection on economic behavior. Therefore, the study of religious beliefs and behavior's interactions in recognition of collective identity of society can reveal extensive and effective role of religious cultural elements.

\section{The Relationship between Religion and Economics}

An overview of Islamic contexts demonstrates the deep bond and reciprocal influence of religion and economics on each other. Holy Quran introduces the economic reform of the society along with calling for unity, the most important missions of prophets, and recalls the efforts of Prophet Shu'aib to improve the economic affairs who said to his people: "O my people! Worship Allah, you have no other God but Him, and give not short measure or weight” (Quran, 11:84). Holy Quran has expressed the direct involvement of some prophets in community planning and economic reform (Quran, 12:47-49; Quran, 12:54-56). In order to this, holy Quran includes numerous verses which are revealed about the importance of economic reform and sometimes has mentioned it in detail (Quran, 2:188; Quran, 2:282; Quran, 4:5-6). In Islam, legitimate economic behavior is considered as worship (HorrAmeli, 1983), and performing religious duties and worship is directly (i.e., Khums and Zakat) or 
indirectly (i.e., effects of bread on praying and fasting) related to economic affairs and sometimes it has significant connection with economic activities (HorrAmeli, 1983; Quran, 22:28). This consideration implies the inextricable connection between religion and economics and demonstrates their mutual influence on each other.

In general, the economic doctrines of Islam can be divided into three categories: Doctrines which indicate the Islamic economic philosophy and worldview issues related to Islam and lessons which are infrastructure and intellectual support of school and economic system of Islam, such as belief in God and his real property; basic rules and guidelines for solving problems and economic goals which govern the planning and policy making of the economy and it is mentioned as "school of economics" like "mixed ownership" and "the need for government intervention”; legal and moral ordinances to regulate economic relations and appropriate economic behavior which create integrated system to achieve favorable economic conditions. These kinds of doctrines play a critical role in economical and educational dimensions. In addition, for providing material and spiritual prosperity of humankind, Islam has suggested best practices in terms of the doctrines presented. In such doctrines, there exist two-way interaction between religion and economy.

From Islamic perspective, economics and economic behavior are completely under the influence of religious beliefs and values. Generally, all programs and economic behavior should be carried out along with religious purposes (Hakimi, Al-Hakimi, \& Al-Hakimi, 1990). Holy Quran considers the purification and training as the philosophy of mission of Prophet Muhammad (pbuh). It also emphasizes the moral and religious philosophy of economic behavior. And, the holy Quran says about Zakat and charity: "Of their wealth take alms to purify and sanctify them” (Quran, 9:103).

However, religion and economic mutually influence each other. As religion and religious ethics have impact on safety performance of economy, economic behavior favorable to Islam also have significant role in strengthening religious beliefs and in spiritual and moral cleansing.

\section{Manifestation of Religion in Economic Behavior of Work and Production}

Production is an activity that leads to creation of products and services by using and organizing a series of factors and inputs, namely labor, asset, and natural resources. Working in different areas has different concepts (MesbahYazdi, 1997). Various definitions have been used for work in the field of economy (Moeedfar, 1999; Tavassoli, 1997). Working is a set of 
actions that the human beings do in the creation of wealth or services using brain, hand, and tools, and these actions in return also affect human and change him (Tavassoli, 1997). Economic activity, from the religious perspective, refers to any activity that is needed to produce goods and required services or to increase the level of public authority and public welfare in the framework of laws and religious values.

\section{Expression of Faith in the Economic Behavior of Distribution and Trade}

Distribution is divided into the "distribution of wealth" and "distribution of goods and services (trade)”. Distribution of wealth includes the principle of God's ownership, the principle of justice, the principle of fraternity, and equality. And, distribution of goods and services refers to spiritual principles, attention to prayer, short-sale denial, the principle of benevolence and negating the deception, forgiveness and leniency in trade, and denial of hoarding.

Crystallization of religious doctrines in the equitable distribution of wealth is based on a set of principles and knowledge infrastructures which requires a great deal of attention. The most important of these principles include the principle of God's ownership, justice, fraternity, and equality which are touched upon briefly below.

From Islamic perspective, God is the rightful owner of the universe and human is the successor of God on earth and trustee of divine. Thus, wealth, facilities, and groundwater resources are not human properties and they have been entrusted to him as loan and for using. This idea has considerable impact on the fair distribution of wealth. It denies the boundaryless freedom of private property which is the origin of inequality and considers moral and spiritual education in training humans. Besides, human beings easily and optionally give part of their wealth and facilities to the poor that is more than their requirements (Quran, 57:7).

Economic justice is one of the most important principles and ultimate goals of Islam. Explanation of justice in the distribution of wealth which is highly emphasized in Islam follows these two purposes: First, it aims at rejecting extremism, financial negligence, and elimination of poverty. It is clear that justice in distribution of wealth and preventing the wealth accumulation related to a specific group lead to poverty eradication. As Imam Kazim (AS) said, if justice has prevailed among people, they were the most needless (Koleini, 1987); second, it considers the material facilities and the full and equal enjoyment of all human from material facilities. This means that welfare should not be allocated to particular 
wealthy minority. This consideration implies that the holy Quran, when ordering the use of blessing, addresses all audiences and views wealth and resources at the disposal of all people (Quran, 2:22; Quran, 7:10; Quran, 14:32).

One of the most comprehensive and effective plans of Islam in building a cohesive society and taking advantage of social justice is creating the bond of brotherhood and fraternity among people of society. Muslim community is considered as a single body that the pain and problem of each individual lead to the suffering of others and their reactions and the fraternal bond is never broken. In explaining this principle, religious doctrines emphasize that fraternity is not just something formal and verbal, but it becomes manifest in terms of rights of believers against one another and it seems that an important part of it tends to be in the economic and financial affairs. To this end, achieving the objective of economic fraternity is displayed in different ways and the most important one is equality.

Considering financial equality of religious brothers is one of the important rights that is emphasized in Hadiths. Equality refers to the state of being equal and participation in subsistence. Some researchers have suggested that equality exists if a person shares cost of his life with another person. Therefore, it is not called equality if someone distributes his wealth only if his earnings exceed his need for money. According to Imam Ali (AS), bond of fraternity is not enriched with anything, except with equality. Also, Imam Sadiq (AS), addressing his Shiite followers, declared that examine our followers in three things: First, examine the importance of prayer times, whether they try to do it on time or not; second, observe them in preserving privacy, whether they are extremely diligent in preserving privacy and confidentiality issues or not; third, consider them in terms of financial strength and in relation with their property that how they share their wealth with their brothers (Saduq, 1984).

\section{Distribution of Goods and Services}

Infrastructures and principles governing the economic behavior in the field of trade which are mentioned in religious doctrines include attention to spiritual principles, attention to prayer, short-sale denial, the principle of benevolence and negating the deception, forgiveness and leniency in dealing, and denial of hoarding.

Market is a symbol of luxurious world which prepares the ground for human neglect. Following this, the importance of the spiritual affairs of the trade is greatly emphasized. Prayer is symbol of remembrance of God (Quran, 20:14) and it is prior to all business 
activities. Imam Sadiq (AS) referred to merchants and declared that no trade and business can prevent them from remembering God and when the time comes for prayer, they stand before God and serve him (Koleini, 1987). Due to this, holy Quran has asserted the need and importance of abandoning transaction for attending the Friday congregational prayer (Quran, 62:9). This highlights that at the time of attending Friday congregational prayer, working in the market and shopping centers is against the orders and economic ethics of Islam.

Short-sale is another symbol of economic oppression and corruption which is severely censured in the holy Quran and Hadiths. There is a surah in the holy Quran named AlMutaffifin that the first verses of it points to short-sellers and their destiny. Also in the holy Quran, 21 verses directly or indirectly have discussed this issue. Holy Quran and Hadiths identify short-sale as a source of exploitation and corruption of society (Quran, 11:85). It is considered as the greatest sin (Sadug, 1984) and its temporal punishment occurs in the form of famine and drought (Koleini, 1987). According to the religion's doctrines, short-selling has pervasive meaning which covers any shortcomings in services to the public (Quran, 11:85).

With regard to the principle of benevolence and negating the deception, it can be argued that deception in trade means withholding all information that the buyer needs to know them and affect his purchase. In traditional doctrines, cheating and deception in trade are strongly blamed and such people have been considered away from the school of holy Prophet and Imams (Koleini, 1987). Adverse consequence of such action is meagerness and struggling in life's bottleneck and such people will be bereft of human care and of the divine bestowals (Majlesi, 1983).

Fraud in the sale of goods like poor supply of goods instead of high quality goods, selling non-standard products, mixing of goods to other things, and the use of false marks are the most striking examples of deception in trade. Also, hiding the defect of product and not making customers aware of its defect is known as deception in trade.

With respect to forgiveness and leniency in trade, it could be argued that leniency in trade and having a genuine customer-friendly behavior strengthen the emotional bonds between people and by attracting more customers it leads to prosperous trade and blessing of wealth. As Prophet Muhammad (pbuh) declared, God bless the one who takes easy in selling, purchasing, paying, and receiving (Tusi, 1987). This is what Muhammad (pbuh), the messenger of God, has stipulated that leniency in trade leads to higher profit (Koleini, 1987).

One of the important aspects of leniency and charity in trade is lending to the poor and deprived such as selling goods on credit and setting deadline for the repayment of debt. This 
is strongly and continually emphasized in the holy Quran and Hadiths. Selling and offering high quality products and satisfactory service delivery and accepting the request of a person for termination of trading who does not have the right to terminate is a kind of human action and remarkable example of trade charity (Koleini, 1987).

One of the religious and economic doctrines in the field of distribution and trade is the denial of hoarding. Hoarding refers to colleting and restriction, and it is used in virtual sense such as gathering and storing food and the like for preservation and future. The legal concept of hoarding can be expressed as custody of goods that people need in the absence and lack of other suppliers with the aim of increment in prices of goods and harm to people. Imam Ali (AS) in a letter to Malik al-Ashtar emphasized the prohibition of hoarding as Muhammad (pbuh), the messenger of God, has forbidden it and stressed to punish those who hoard after prohibition. Also, it was asked from Imam Sadiq (AS) about a hoarder who is waiting for food price rising and he replied that if food is low and it is not enough for the need of all people, in this case food hoarding and paying less attention to people are disagreeable (Koleini, 1987).

\section{Concluding Remarks}

Not only Islam does not agree with forgetting and leaving the world behind but also it encourages Muslims for doing useful economic activities. Islam does not observe production, trade, and acquiring wealth harmful if it is achieved through appropriate way. Besides, Islam considers production, trade, and acquiring wealth as prerequisites for economic growth and development because development means giving attention to all aspects of life. In fact, since Islam considers welfare in spiritual and material dimensions, so it creates a balance between the spiritual and material dimensions of human. It is obvious that transferring a part of excessive consumption of rich people to low-income groups will increase the total utility and welfare of community. The total utility of low-income groups is much more than the rich. Also, increasing in purchasing power of low-income groups and equitable distribution of goods and services among all members of society accelerate economic development through increased productivity and economic balance. Therefore, the role and importance of economic balance in creation of grounds for economic activities and rational human behavior is transparent. Hence, it can be concluded that Islam encourages work in general and trade and commerce in particular. Honesty in business dealing is also important in Islam. There should be plain dealing between seller and buyer. If seller attempts to sell his products or 
things on fake basis then he will be guilty of that. Islam criticizes all dishonest and illegal business dealings. As a Muslim, we should always live the way God has taught us and delivered a great messenger to teach us the appropriate way of functioning well for now and in the hereafter.

In sum, ethic continues to be a major force shaping contemporary world. Like other religions, Islam highlights the importance of looking beyond personal short-term gains and it observes the wide implications of human action. The current study showed the importance of business ethics from the perspective of Islamic economic. Also, it revealed that ethics had an especially beneficial impact on attitudes. Application of principles of Islamic ethics is required from all Muslims. From the Islamic perspective, these rules are not due to societal acceptance; since they are divine and are arranged for the benefit and happiness of society and individuals. It is more desirable that this research be applied, adopted, and extended to practical contexts. Also, it can be replicated in other settings and religions communities which would allow for more generalizations to be made.

\section{References}

Baker, S. D., \& Comer. D. R. (2012). Business ethics everywhere: An experiential exercise to develop students' ability to identify and respond to ethical issues in business. Journal of Management Education. 36(1), 95-125.

Chryssides, G. D., \& Kaler, J. H. (1993). An introduction to business ethics. London: Chapman \& Hall.

Hakimi, M. R., Al-hakimi, M., \& Al-Hakimi, A. (1990). Al-Hayat (1 $1^{\text {st }}$ ed.). Tehran: Maktab Nashr Al-Thagafah AlIslammiyyah.

Horr Ameli, M. E. A. (1983). Vasael alshie ela tahsil masael alsharia (6 ${ }^{\text {th }}$ ed.). Tehran: Maktab al-Islamiyyah.

Irvani, J. (2006). Economic ethic in the Quran and Hadith (1 $1^{\text {st }}$ ed.). Mashhad: Razavi University of Islamic Sciences.

Jones, C. (2003). As if business ethics were possible, ‘within such limits'.... Organization, 10(2), 223-248.

Jones, C., Parker, M., \& Ten Bos, R. (2005). For business ethics. London: Routledge.

Koleini, M. I. Y. (1987). Al-Kafi (4 ${ }^{\text {th }}$ ed.). Tehran: Dar al-Kotob al-Islamiyyah.

Majlesi, M. B. (1983). Bahar al-Anvar ( $3^{\text {rd }}$ ed.). Beirut: Alvafa.

Mesbah Yazdi, M. T. (1997). Morality of the Quran (1 ${ }^{\text {st }}$ ed.). Qom: Imam Khomeini Educational and Research Institute.

Moeedfar, Saeed. (1999). Evaluation of work ethics and personal and social factors affecting it (1 $1^{\text {st }}$ ed.). Tehran: Labor and Social Security Institute.

Mosely, D. C., Pietri, P. H., \& Megginson, L. C. (1996). Management: Leadership in action (5 ${ }^{\text {th }}$ ed.). New York: Harper Collins College.

Naqvi, S. N. H. (1994). Islam, economics, and society. London: Kegan Paul International.

Quddus, M., Bailey. III. H., \& White, L, R. (2009). Business ethics: perspectives from Judaic, Christian, and Islamic scriptures. Journal of Management, Spirituality, \& Religion, 6(4), 323-334.

Saduq, M. (1984). Al-Amali (4 ${ }^{\text {th }}$ ed.). Tehran: Islamiyyah Bookstore Publication.

Schwartz, M. S., \& Weber, J. (2006). Measuring business ethics activity around the world. Business \& Society, 45(3), 382405.

Shaw, W. H. (1999). Business ethics. Belmont, CA: Wadsworth. 
Sternberg, E. (2000). Just business: Business ethics in action ( $2^{\text {nd }}$ ed.). New York: Oxford University Press.

Stewart, D. (1996). Business ethics. New York: McGraw-Hill.

Tavassoli, G. (1997). Sociology of work and jobs (1 $1^{\text {st }}$ ed.). Tehran: SAMT.

Tusi, M. I. H. (1087). Tahzib al-Ahkam (4 ${ }^{\text {th }}$ ed.). Tehran: Dar al-Kotob al-Islamiyyah.

Wang, Y., \& Yang. F. (2011). Muslim attitudes toward business in the emerging market economy of China. Social Compass, 58(4), 554-573.

Weiss, J. W. (1994). Business ethics. Belmont, CA: International Thompson. 